\title{
Relation between relative growth rate and tipburn occurrence of romaine lettuce under different light regulations in a plant
} factory with LED lighting

\author{
Wenshuo $\mathrm{Xu}^{1}$, D.T.P. Nguyen ${ }^{1}$, Shunsuke Sakaguchi ${ }^{2}$, Takuji Akiyama ${ }^{2}$, Satoru Tsukagoshi ${ }^{3}$, A. Feldman ${ }^{3}$ \\ and $\mathrm{Na} \mathrm{Lu}^{3}$ \\ ${ }^{1}$ Graduate School of Horticulture, Chiba University, Matsudo, Chiba, Japan \\ 2 PlantX Corporation, Wakashiba, Kashiwa, Chiba, Japan \\ ${ }^{3}$ Center for Environment, Health and Field Sciences, Chiba University, Kashiwa, Chiba, Japan
}

\section{Summary}

Plant factories or vertical farms with LED lighting have been developed to grow fresh and high-quality vegetables inside urban buildings without being restricted by climate and land. Environmental control technologies are developing rapidly for improving productivity of leafy vegetables in plant factories. However, tipburn issues are also rising with the increase of plant growth rate and this reduces the product quality and its marketable value. The tip-burned parts of the vegetable must be removed manually at harvest, which causes more yield loss and labor cost. In this research, the effects of light intensities with different total light integrals (TLI) or with the same TLI on lettuce growth and tipburn occurrence were investigated. In the first experiment, three light intensities: 85,125 , and $187 \mu \mathrm{mol} \mathrm{m} \mathrm{m}^{-2} \mathrm{~s}^{-1}$ were applied to the rapid growth stage of romaine lettuce plants; and in the second experiment, an average light intensity of $150 \mu \mathrm{mol} \mathrm{m}{ }^{-2} \mathrm{~s}^{-1}$ was applied in four different lighting patterns to the plants. The results show that plant biomass clearly increased with increases of light intensity (or TLI) but was not affected by different lighting patterns under the same TLI. Leaf areas were not significantly affected by different light intensities under the present experimental conditions, indicating that plants firstly expand leaf area (rather than increase thickness) to increase light interception when light intensity is low. Tipburn occurred during 23 26 days after sowing and its occurrence was positively correlated with light intensity and relative growth rate (RGR). Regression analysis indicated that there could be a key threshold value in RGR which induces tipburn. To control an RGR value lower than the threshold value during 23 26 days after sowing would be critical for limiting tipburn occurrence.

Keywords

artificial lighting, lettuce growth stage, light intensity, RGR value, total light integral, indoor farming

\section{Introduction}

Plant factories or vertical farms have been developed to grow fresh and high-quality vegetables inside urban buildings without being restricted by climate and land. Especially

\section{Significance of this study}

What is already known on this subject?

- Tipburn issues reduce lettuce quality and its marketable value. Tipburn is usually rising with the increase of plant growth rate. Light is one of the most important factors affecting plant growth rate in plant factories.

What are the new findings?

- By applying different light intensities at different growth stages of lettuce, plant growth rate will be regulated, thus the tipburn occurrence can be controlled. A key relative growth rate (RGR) threshold was indicated for controlling tipburn occurrence during 23 26 days after sowing.

What is the expected impact on horticulture?

- This study will provide important timing and RGR value for growers who use plant factories with artificial lighting to limit tipburn occurrence.

for those large cities that need fresh, safe, high-nutrient level, good taste, and local produced vegetables, plant factory is an important solution to meet these demands (Kozai and Niu, 2016). Many environmental control technologies are being developed to improve production of leafy vegetables grown in plant factories (Tong et al., 2014; Zhang et al., 2018). Lettuce is one of the most widely planted leafy vegetables in plant factory. Its commercial value has always been influenced by tipburn which is usually rising with the increase of plant growth rate (Cox et al., 1976). Tipburn is a physiological disorder and expressed as a necrosis in the margins of young developing leaves. Initially small brown spots form on the leaf edge, and then the spots slowly converge, and finally whole leaves become brown and necrotic. This kind of disorder heavily influences the appearance of the product, and thus reduces the acceptance of buying the product by consumers. The producers must remove the tip-burned part manually when harvesting, which means more yield loss and more labor cost.

Research so far have shown that tipburn occurrence is influenced by many environmental factors. Air supply to inner developing leaves was proved effective in preventing tipburn without decreasing growth rate (Goto, 1992). Shortening day/night cycle without changing the total lighting 
period reduced tipburn occurrence without reducing growth rate (Goto and Takakura, 2003). Tipburn symptoms were delayed when decreasing relative humidity from $74 \%$ to $51 \%$ during the light period in lettuce (Collier and Tibbitts, 1984). Nightly irrigation with a solution of calcium nitrate (Cresswell, 1991), spraying calcium on leaf surface (Corriveau et al., 2017), spraying exogenous spermidine onto leaves (Yang et al., 2018), and controlling $\mathrm{K}: \mathrm{Ca}$ ratio in nutrient solution (Huett, 1994) were effective ways of minimizing tipburn occurrence.

Possible mechanisms of how tipburn was influenced by different factors in lettuce were summarized by Collier and Tibbitts (1982). They reported that rapid growth encouraged by environmental conditions is one of the factors that stimulates tipburn. Rapid growth rate associated with a high assimilatory activity in the leaves, resulted in a lack of calcium in the young developing leaves. Low calcium concentrations in cells cause loss of membrane integrity and weakness in cell wall structure, which further lead to laticifer disruption and cell collapse, finally resulting in tissue collapse and tipburn development. Other investigators also indicated that calcium deficiency which correlated with high plant growth rate may be the reason of tipburn symptoms (Cox et al., 1976; Barta and Tibbits, 1991; Sago, 2016). Misaghi and Grogan (1978) reported that higher air temperature $\left(33^{\circ} \mathrm{C}\right)$ tended to cause greater tipburn severity index and higher percentage of tipburned plants, compared with lower air temperature $\left(24^{\circ} \mathrm{C}\right)$. The difference in tipburn occurrence also varies largely among different lettuce varieties. Butterhead lettuce was proved more sensitive to tipburn compared with leaf lettuce under same air temperature condition (Choi et al., 2004).

Light intensity largely affects the growth rate of plants, and indirectly affects the occurrence of leaf tipburn in plants (Tibbitts and Rao, 1968). Electricity cost accounts for a high proportion (about 25-30\%) of the total production cost in plant factory (Kozai et al., 2015). It can be reduced by improving efficient use of light energy to enhance growth and reduce tipburn of plants. Son and Takakura (2010) found that the tipburn occurrence of lettuce happened later under the conditions that light intensity was low and duration of lighting cycle was short. With the increase of light intensity, fresh and dry weights of shoots, relative growth rate, and the number of tipburned leaves significantly increased (Sago, 2016). Thus, we hypothesize that to change light strategy during different plant growth stages could control plant growth rate, thus reducing its tipburn occurrence. In this study, we aimed to investigate the effects of lighting regulation on lettuce growth and tipburn occurrence. A key threshold value of RGR which may induce tipburn was determined for establishing a good tool for producers.

\section{Materials and methods}

\section{Plant materials and growth conditions}

The experiments were conducted in a plant factory with artificial light of $400 \mathrm{~m}^{2}$ (facility floor area) where the environmental conditions are controlled. Romaine lettuce (Lactuca sativa L. var. Romaria, Takii Seed Co., Ltd., Kyoto, Japan) seeds were sown in urethane sponge seeding mats (LWH: $28 \mathrm{~cm}$, $58 \mathrm{~cm}, 2.8 \mathrm{~cm}$ ) consisting of 300 sponge blocks (LWH: $2.3 \mathrm{~cm}$, $2.3 \mathrm{~cm}, 2.8 \mathrm{~cm}$ ) per mat. At 12 days after sowing, uniform seedlings were planted into 26-hole panels ( $\mathrm{LWH}: 29.8 \mathrm{~cm}$, $59.6 \mathrm{~cm}, 1.4 \mathrm{~cm}$; the dimension of each hole is $2.2 \mathrm{~cm}$ in diameter, $1.4 \mathrm{~cm}$ in depth). The light intensity (LI) for seedlings was $150 \mu \mathrm{mol} \mathrm{m}^{-2} \mathrm{~s}^{-1}$ and a photoperiod of $16 \mathrm{~h}$ per day was provided by white LED lamps (Oval Tube UBT818W-5000, Nikken Hardware Corp., Japan). The seedlings were grown in a deep-flow hydroponic system with Enshi formula nutrient solution, and the electrical conductivity (EC) was set at $1.5 \mathrm{dS} \mathrm{m}^{-1}$ with a pH of 5.5-6.5 and a flow rate of $10 \mathrm{~L} \mathrm{~min}^{-1}$. Air temperature, relative humidity, and $\mathrm{CO}_{2}$ concentration were set to $21^{\circ} \mathrm{C}, 70 \pm 10 \%$, and $1,500 \mathrm{ppm}$, respectively.

\section{Treatments}

At 23 days after sowing (at the end of day 23), the lettuce seedlings were transplanted into 6-hole panels (the dimension of each hole is the same as described above) and cultivated for 9 days (in the first experiment) or 12 days (in the second experiment). In the first experiment, uniform seedlings were subjected to three photosynthetic photon flux density (PPFD) levels (Low, Middle, High; L, M, H, hereafter) from day 24 (D 24) to D 32 (Table 1). Plants were sampled every 3 days ( 4 times, 10 plants/time) on D 23, D 26, D 29, and were harvested on D 32. In the second experiment, total light integral (TLI, defined in Table 2) were the same among different treatments, but different light intensities were applied in different stages (three stages, each stage including 4 days) of product period. The average light intensity was maintained at $150 \mu \mathrm{mol} \mathrm{m} \mathrm{m}^{-2} \mathrm{~s}^{-1}$. Four different treatments (T1, T2, T3, T4, hereafter) were implemented in the second experiment (Table 2). Plants were sampled every 4 days on D 23, D 27, D 31, D 35, and all plants were harvested on D 35.

In both experiments, photoperiod was $16 \mathrm{~h}$ per day supplied by white LED lamps (Oval Tube UBT818W-5000, Nikken Hardware Corp., Japan). Lettuces were grown in a deep-flow hydroponic system in nutrient solution (Chiba-U formula as above) with an EC of $2.2 \mathrm{dS} \mathrm{m}^{-1}$, a pH of 5.5-6.5 and a flow rate of $10 \mathrm{~L} \mathrm{~min}^{-1}$. Air temperature, relative humidity, and $\mathrm{CO}_{2}$ concentration were same as seedling stage. Light intensity was measured at the surface of the panels using a Li-250 quantum sensor (Li-Cor Inc., Lincoln, NE, USA) before placing the plants.

TABLE 1. Light intensities on different stages of product period and total light integrals (TLI) in different treatments in the first experiment.

\begin{tabular}{lcccc}
\hline \multirow{2}{*}{ Treatment } & \multicolumn{3}{c}{ Light intensity $\left(\mu \mathrm{mol} \mathrm{m}^{-2} \mathrm{~s}^{-1}\right)$} & $\mathrm{TLI}\left(\mathrm{mol} \mathrm{m}^{-2}\right)$ \\
\cline { 2 - 5 } & $\mathrm{D} 24 \sim 26$ & $\mathrm{D} 27 \sim 29$ & $\mathrm{D} 30 \sim 32$ & $\mathrm{D} 24 \sim 32$ \\
\hline Low LI (L) & 85 & 85 & 85 & 44.1 \\
Middle LI (M) & 125 & 125 & 125 & 64.8 \\
High LI (H) & 187 & 187 & 187 & 96.9 \\
\hline
\end{tabular}

Low LI (L): lettuce were grown under $85 \mu \mathrm{mol} \mathrm{m} \mathrm{m}^{-2} \mathrm{~s}^{-1}$ from $\mathrm{D} 24$ to $\mathrm{D} 32$.

Middle LI (M): lettuce were grown under $125 \mu \mathrm{mol} \mathrm{m}^{-2} \mathrm{~s}^{-1}$ from D 24 to D 32 .

High LI (H): lettuce were grown under $187 \mu \mathrm{mol} \mathrm{m}^{-2} \mathrm{~s}^{-1}$ from $D 24$ to $D 32$.

TLI was calculated as follows: TLI $\left(\mathrm{mol} \mathrm{m}^{-2}\right)=\operatorname{PPFD}\left(\mu \mathrm{mol} \mathrm{m} \mathrm{m}^{-2} \mathrm{~s}^{-1}\right) \times$ photoperiod $\left(\mathrm{h} \mathrm{d}^{-1}\right) \times 3,600\left(\mathrm{~s} \mathrm{~h}^{-1}\right) \times(32-23)($ days $) \times 10^{-6}$. 
TABLE 2. Light intensities in different stages of product period and total light integrals (TLI) in different treatments in the second experiment.

\begin{tabular}{lcccccc}
\hline & \multicolumn{3}{c}{$\begin{array}{c}\text { Light intensity } \\
\left(\mu \mathrm{mol} \mathrm{m}^{-2} \mathrm{~s}^{-1}\right)\end{array}$} & $\begin{array}{c}\text { TLI } \\
\left(\mathrm{mol} \mathrm{m}^{-2}\right)\end{array}$ \\
\cline { 2 - 7 } Treatment & $\mathrm{D} 24 \sim 27$ & $\mathrm{D} \mathrm{28} \mathrm{31}$ & $\mathrm{D} \mathrm{32} \mathrm{35}$ & $\mathrm{D} 24 \sim 27$ & $\mathrm{D} 24 \sim 31$ & $\mathrm{D} \mathrm{24 \sim 35}$ \\
\hline T1 & 150 & 150 & 150 & 34.6 & 69.1 & 103.7 \\
T2 & 100 & 150 & 200 & 23.0 & 57.6 & 103.7 \\
T3 & 150 & 100 & 200 & 34.6 & 57.6 & 103.7 \\
T4 & 200 & 100 & 150 & 46.1 & 69.1 & 103.7 \\
\hline
\end{tabular}

T1: lettuces were grown under $150 \mu \mathrm{mol} \mathrm{m} \mathrm{m}^{-2} \mathrm{~s}^{-1}$ from D 24 D 35 .

T2: lettuces were grown under 100, 150, $200 \mu \mathrm{mol} \mathrm{m}^{-2} \mathrm{~s}^{-1}$ during D 24 27, D 28 31, D 32 35, respectively.

T3: lettuces were grown under 150, 100, $200 \mu_{\mathrm{mol} \mathrm{m}}^{-2} \mathrm{~s}^{-1}$ during D 24 27, D 28 31, D 32 35, respectively.

T4: lettuces were grown under 200, 100, $150 \mu \mathrm{mol} \mathrm{m}^{-2} \mathrm{~s}^{-1}$ during D 24 27, D 28 31, D 32 35, respectively.

TLI was calculated as follows: TLI $\left(\mathrm{mol} \mathrm{m}^{-2}\right)=\operatorname{PPFD}\left(\mu \mathrm{mol} \mathrm{m}^{-2} \mathrm{~s}^{-1}\right) \times$ photoperiod $\left(\mathrm{h} \mathrm{d}^{-1}\right) \times 3,600\left(\mathrm{~s} \mathrm{~h}^{-1}\right) \times$ treatment days $\times 10^{-6}$.

\section{Measurements}

In the first experiment, plants were sampled on D 23 (transplanting day), D 26, D 29, D 32, and harvested on D 32. In the second experiment, growth measurements and sampling were performed on D 23 (transplanting day), D 27, D 31, and D 35 (harvest day). Leaf area, shoot and root fresh weights were evaluated on each sampling date. Leaf area per plant was determined using a Li-3000 leaf area meter (Li-Cor, Lincoln, NE, USA). Shoot and root dry weights were measured after oven-drying at $80^{\circ} \mathrm{C}$ for at least 4 days. Marketable Fresh Weight (FW, g) was calculated using the following equation: Marketable fresh weight $=$ (total shoot fresh weight) - (fresh weight trimmed from tip-burned leaves). Leaf mass per area (LMA) $\left(\mathrm{g} \mathrm{m}^{-2}\right)$ was calculated from the shoot dry weight and total leaf area (shoot dry weight/total leaf area). Relative growth rate (RGR) $\left(\mathrm{g} \mathrm{d}^{-1}\right)$ was calculated using the following equation: $\mathrm{RGR}=\left[\ln \left(\mathrm{W}_{\mathrm{i}}\right)-\ln \left(\mathrm{W}_{23}\right)\right] /$ $\left(t_{i}-t_{23}\right)$ where $W_{i}$ and $W_{23}$ are shoot dry weights of lettuce at day $i$ and day 23 after sowing, respectively. Tipburn occurrence was calculated by the following equation: Tipburn occurrence $=\left(\mathrm{N}_{2} / \mathrm{N}_{1}\right) * 100 \%$ where $\mathrm{N}_{1}$ is the total number of samples, $\mathrm{N}_{2}$ is the number of tipburned-plants. To determine the relationships between tipburn development and plant growth rate, a correlation analysis was performed between the percentage of tipburned plants and the relative growth rate.

\section{Statistical analysis}

Six to ten plants were sampled on each sampling date in each treatment to evaluate overall parameters. Significant differences between treatments for lettuce were analyzed by Tukey's test using SPSS statistical software (IBM SPSS Statistics, v. 19.0. Armonk, NY, USA; IBM Corp.). Differences were considered significant at $P<0.05$.

\section{Results}

\section{Experiment 1. Effects of PPFD on plants growth and tipburn occurrence}

Shoot \& root fresh weight (FW) and dry weight (DW) increased with increasing light intensity. Those were significantly higher under the highest light intensity $(H)$ than the lowest light intensity (L) after day 29 (Figure 1). There was no significant difference in leaf area (LA) among different light intensity treatments (Figure 2A). However, the leaf mass per area (LMA) increased with the increases of light intensity (Figure 2B), due to the difference in shoot dry weight (Figure 1C).

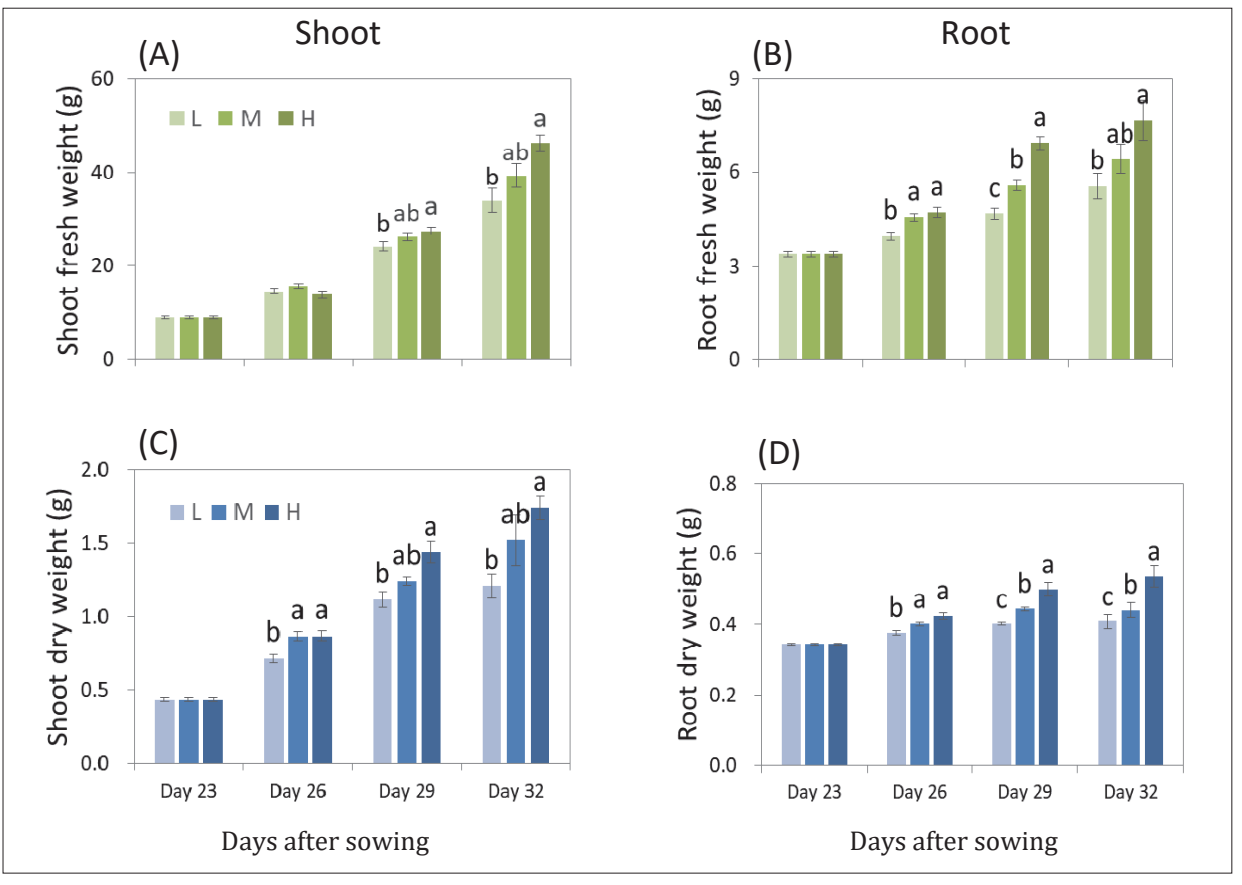

Figure 1. The shoot $(\mathrm{A}, \mathrm{C})$ and root $(B, D)$ fresh weights (A, B) and dry weights (C, D) at $23,26,29$, and 32 days after sowing in Exp. 1. L (low light intensity): lettuce were grown under $85 \mu \mathrm{mol} \mathrm{m} \mathrm{m}^{-2} \mathrm{~s}^{-1}$ from D 23 to D 32; M (middle light intensity): lettuce were grown under $125 \mu \mathrm{mol} \mathrm{m}{ }^{-2} \mathrm{~s}^{-1}$ from D 23 to D 32; H (high light intensity): lettuce were grown under $187 \mu \mathrm{mol} \mathrm{m}{ }^{-2} \mathrm{~s}^{-1}$ from D 23 to D 32. Data are shown as the mean \pm SE. Different letters indicate significant differences between light treatments $(P<0.05$, Tukey's test). 


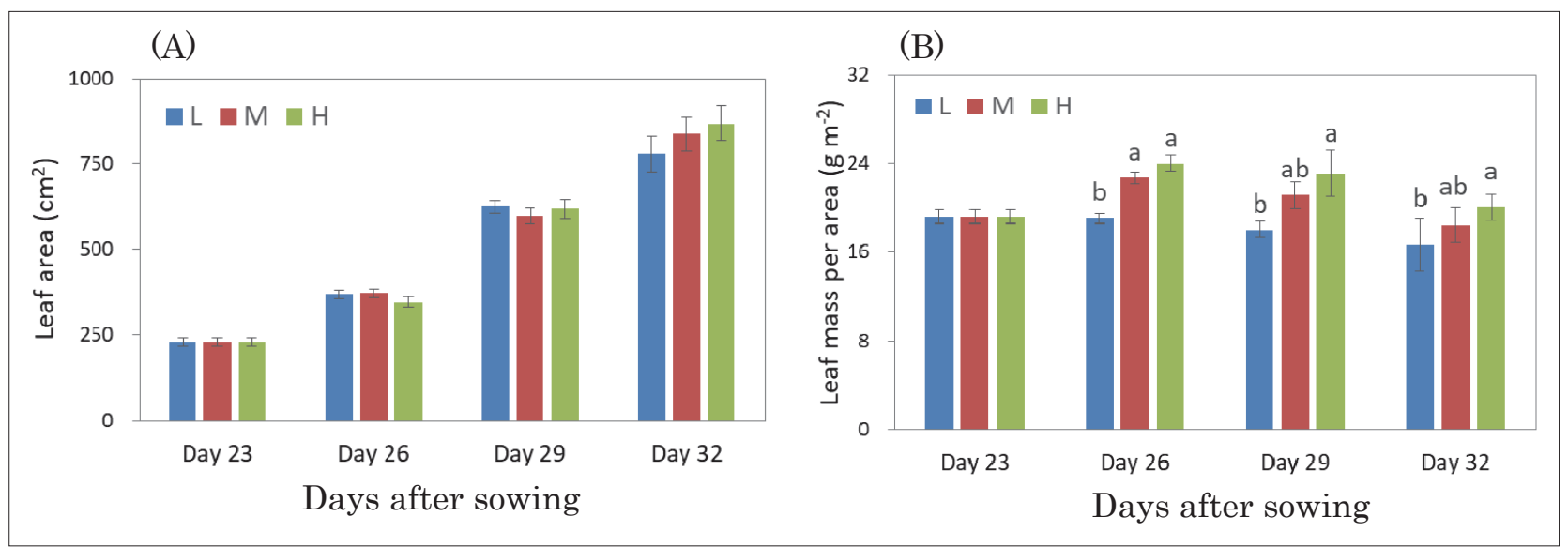

FigurE 2. Leaf area (A) and leaf mass per area (B) at 23, 26, 29 and 32 days after sowing. L (low light intensity): lettuce were grown under $85 \mu \mathrm{mol} \mathrm{m}{ }^{-2} \mathrm{~s}^{-1}$ from D 23 to D 32; M (middle light intensity): lettuce were grown under $125 \mu \mathrm{mol} \mathrm{m}^{-2} \mathrm{~s}^{-1}$ from D 23 to D 32; $\mathrm{H}$ (high light intensity): lettuce were grown under $187 \mu \mathrm{mol} \mathrm{m}^{-2} \mathrm{~s}^{-1}$ from D 23 to D 32 . Data are shown as the mean $\pm \mathrm{SE}, n=6$. Different letters indicate significant differences between light treatments $(P<0.05$, Tukey's test).

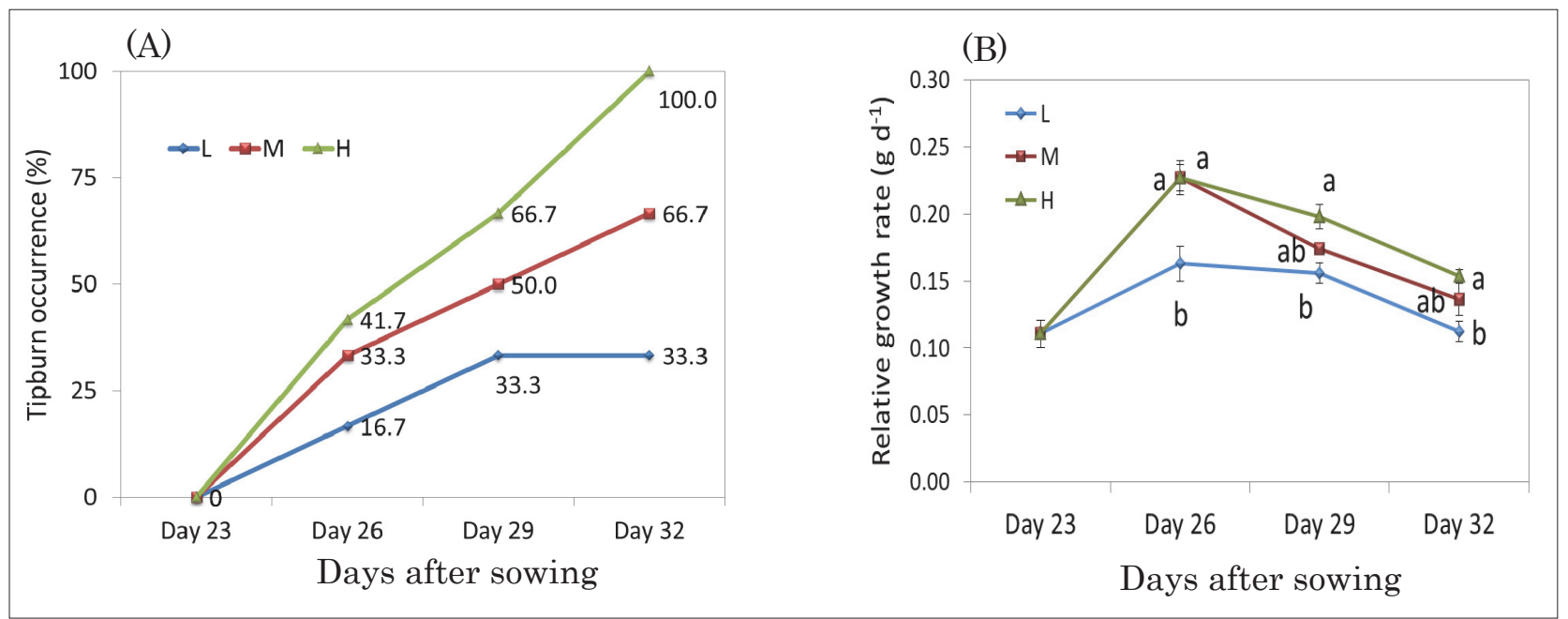

FIGURE 3. Tipburn occurrence (A) and relative growth rate (B) at 23, 26, 29 and 32 days after sowing. L (low light intensity): lettuce were grown under $85 \mu \mathrm{mol} \mathrm{m}^{-2} \mathrm{~s}^{-1}$ from D 23 to D 32; M (middle light intensity): lettuce were grown under $125 \mu \mathrm{mol}$ $\mathrm{m}^{-2} \mathrm{~s}^{-1}$ from D 23 to D 32; H (high light intensity): lettuce were grown under $187 \mu \mathrm{mol} \mathrm{m}^{-2} \mathrm{~s}^{-1}$ from D 23 to D 32 . For Figure B, data are shown as the mean $\pm \mathrm{SE}, n=5$. Different letters indicate RGR significant differences between light treatments at the same day $(P<0.05$, Tukey's test).

In this experiment, tipburn were observed on day 26 after sowing. Higher light intensity induced higher tipburn occurrence $(\mathrm{H}>\mathrm{M}>\mathrm{L})$ on D 26, D 29, and D 32, respectively. Under $187 \mu \mathrm{mol} \mathrm{m}{ }^{-2} \mathrm{~s}^{-1}$ treatment, the tipburn occurrence reached $100 \%$ on D 32 (Figure 3A). RGRs were increasing with time during D 23 to D 26 and reached the highest value on D 26, then decreasing with time during D 26 to D 32. RGR value followed: $\mathrm{H}>\mathrm{M}>\mathrm{L}$ (Figure $3 \mathrm{~B}$ ).

On D 23, RGR value was 0.11 , and tipburn occurrence (TB) value was 0 . On D 26, under $85 \mu \mathrm{mol} \mathrm{m}^{-2} \mathrm{~s}^{-1}$ treatment, $\mathrm{RGR}=0.16, \mathrm{~TB}=16.7 \%$. Under $125 \mu \mathrm{mol} \mathrm{m} \mathrm{m}^{-2} \mathrm{~s}^{-1}$ treatment, $\mathrm{RGR}=0.23, \mathrm{~TB}=33.3 \%$. Under $187 \mu \mathrm{mol} \mathrm{m} \mathrm{m}^{-2} \mathrm{~s}^{-1}$ treatment, $\mathrm{RGR}=0.23, \mathrm{~TB}=41.7 \%$. Correlation between RGR and tipburn occurrence was evaluated with Pearson's correlation coefficient, and a positive correlation was found $(r=0.95)$. Through regression analysis, a liner relationship between RGR and tipburn occurrence is obtained:

$$
\mathrm{Y}=0.0028 \mathrm{x}+0.1214\left(\mathrm{R}^{2}=0.89\right)
$$

This formula indicated that tipburn would appear when RGR is higher than 0.1214 . Thus, $R G R<0.12$ seemed to be a key point to reduce tipburn occurrence (Figure 4).

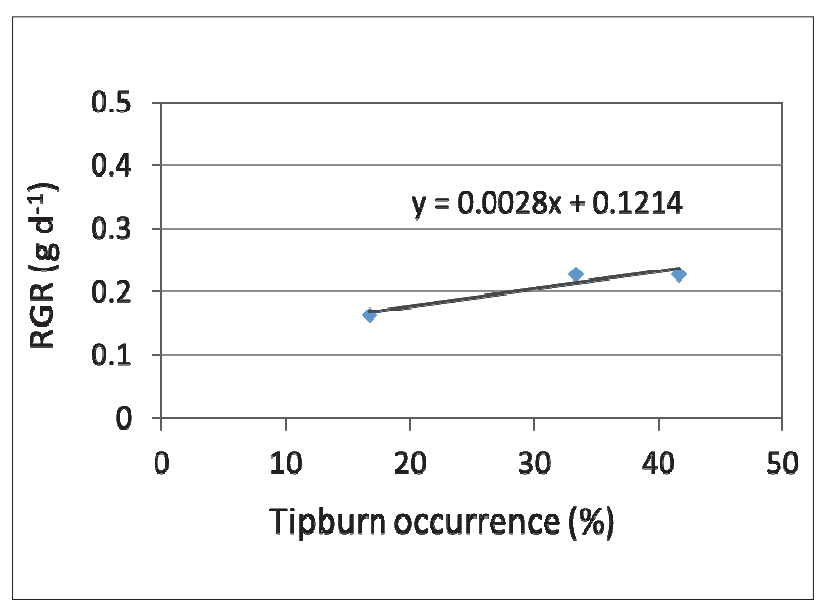

FIGURE 4. Relation between RGR and Tipburn occurrence at 26 days after sowing. 

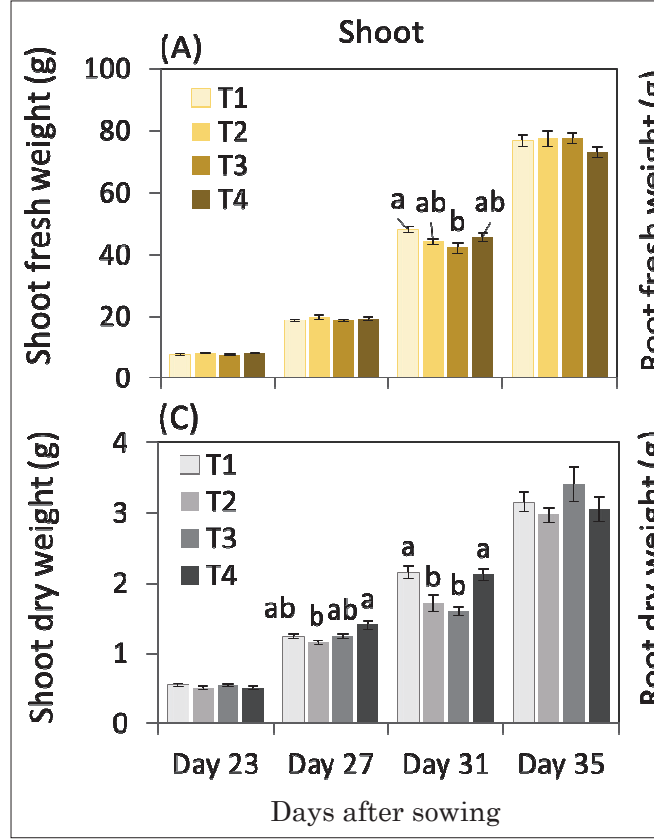

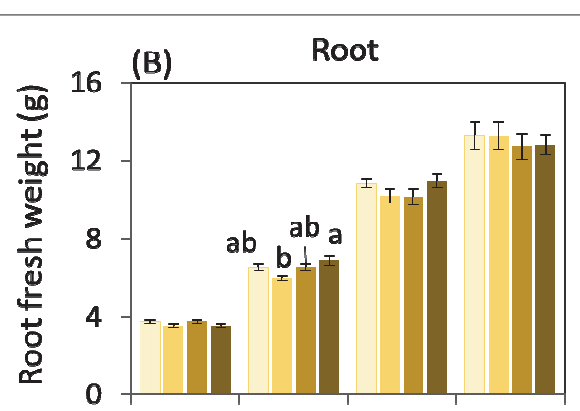

(D)

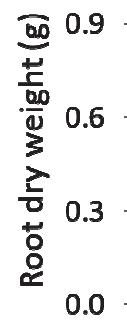

0.0

Day 23 Day 27 Day 31 Day 35 Days after sowing

Figure 5. The shoot $(A, C)$ and root $(B, D)$ fresh weights $(A, B)$ and dry weights $(C, D)$ at 23,27 , 31 , and 35 days after sowing. T1: lettuces were grown under $150 \mu \mathrm{mol} \mathrm{m}{ }^{-2} \mathrm{~s}^{-1}$ from D 23 D 35. T2: lettuces were grown under $100,150,200 \mu \mathrm{mol} \mathrm{m}^{-2} \mathrm{~s}^{-1}$ during D 23 27, D 28 31, D 32 35, respectively. T3: lettuces were grown under 150, 100, $200 \mu \mathrm{mol}$ $\mathrm{m}^{-2} \mathrm{~s}^{-1}$ during D 23 27, D 28 31, D 32 35, respectively. T4: lettuces were grown under 200,100 , $150 \mathrm{~mol} \mathrm{~m}^{-2} \mathrm{~s}^{-1}$ during D 23 27, D 28 31, D 32 35, respectively. Data are shown as the mean $\pm \mathrm{SE}, n=10$. Different letters indicate significant differences between light treatments $(P<0.05$, Tukey's test).

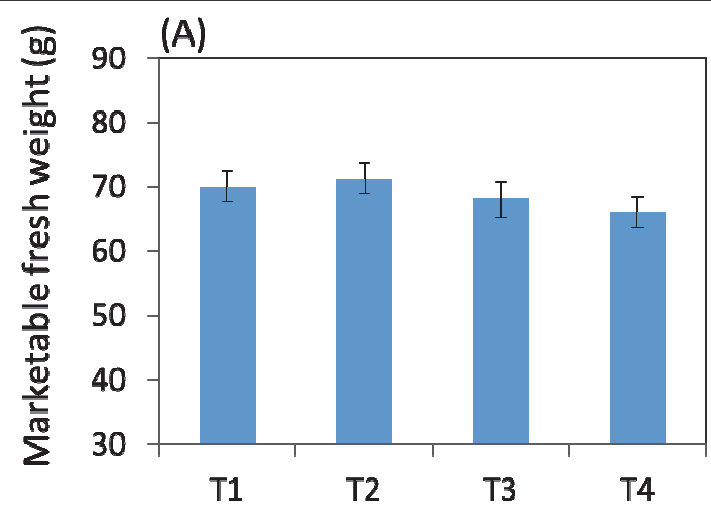

Lighting treatments
(B)

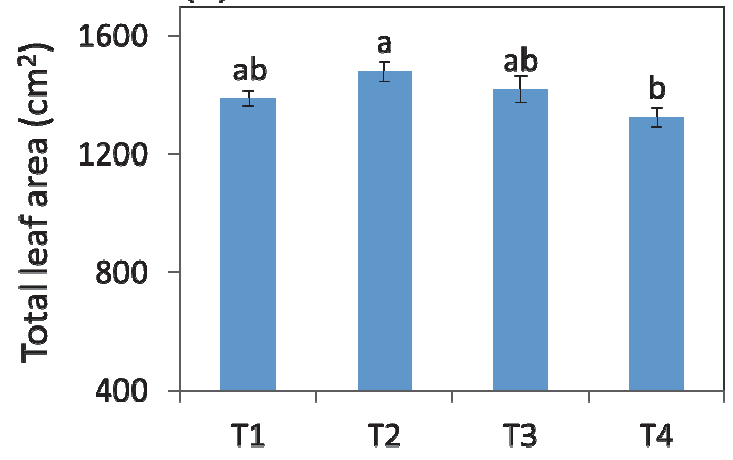

Lighting treatments

FIGURE 6. Marketable fresh weight (A) and Total leaf area (B) under different light treatment at 35 days after sowing. Marketable fresh weight $=$ (total shoot fresh weight) - (fresh weight trimmed from tip-burned leaves). T1: lettuces were grown under $150 \mu \mathrm{mol} \mathrm{m}^{-2} \mathrm{~s}^{-1}$ from D 23 D 35. T2: lettuces were grown under 100, 150, $200 \mu \mathrm{mol} \mathrm{m}^{-2} \mathrm{~s}^{-1}$ during D 23 27, D 28 31, D 32 35, respectively. T3: lettuces were grown under 150, 100, $200 \mu \mathrm{mol} \mathrm{m}^{-2} \mathrm{~s}^{-1}$ during D 23 27, D 28 31, D 32 35, respectively. T4: lettuces were grown under 200, 100, $150 \mu \mathrm{mol} \mathrm{m}^{-2} \mathrm{~s}^{-1}$ during D 23 27, D 28 31, D 32 35, respectively. Data are shown as the mean \pm SE, $n=6$. Different letters indicate significant differences between light treatments $(P<0.05$, Tukey's test $)$.

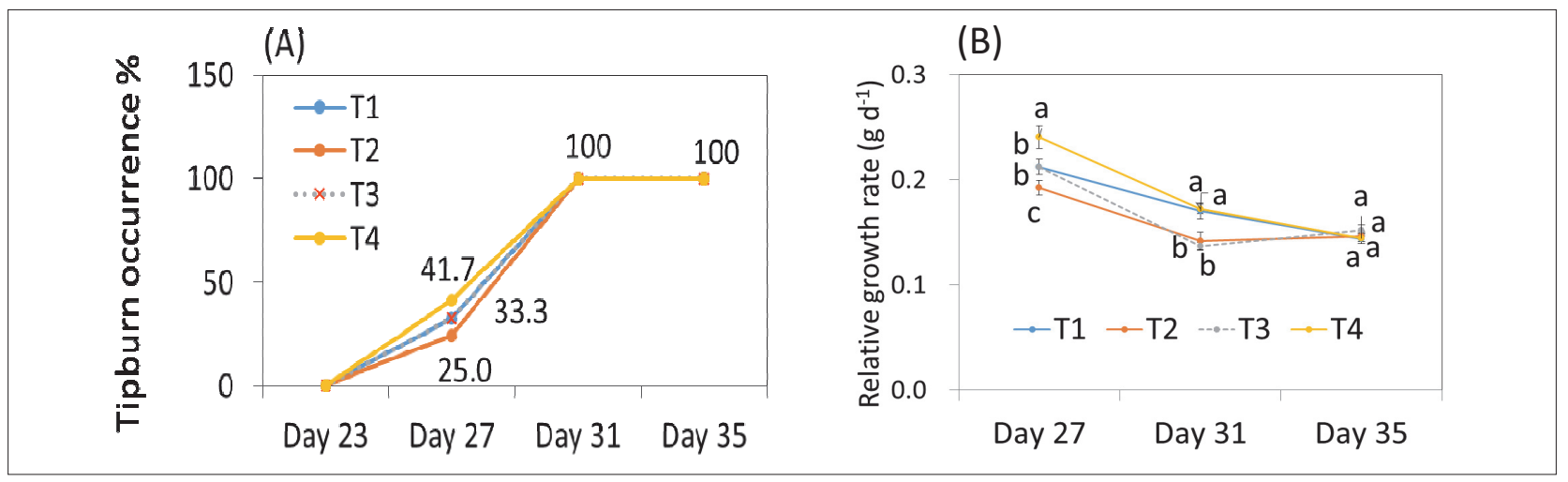

FIGURE 7. Tipburn occurrence and RGR at different days and their relation at 27 days after sowing. T1: lettuces were grown under $150 \mu \mathrm{mol} \mathrm{m}^{-2} \mathrm{~s}^{-1}$ from D 23 D35. T2: lettuces were grown under 100, 150, $200 \mu \mathrm{mol} \mathrm{m}^{-2} \mathrm{~s}^{-1}$ during D 23 27, D 28 31, D 32 35, respectively. T3: lettuces were grown under 150,100, $200 \mu \mathrm{mol} \mathrm{m}^{-2} \mathrm{~s}^{-1}$ during D 23 27, D 28 31, D 32 35, respectively. T4: lettuces were grown under 200,100, $150 \mu \mathrm{mol} \mathrm{m} \mathrm{m}^{-2} \mathrm{~s}^{-1}$ during D 23 27, D 28 31, D 32 35, respectively. Data are shown as the mean $\pm \mathrm{SE}, n=6$. Different letters indicate significant differences between light treatments $(P<0.05$, Tukey's test). 


\section{Experiment 2. Effects of changing light intensities in different stages of product period (with the same TLI) on plant growth and tipburn occurrence}

On D 27, shoot and root DWs under T4 were higher than those of $\mathrm{T} 2$, followed the findings in the first experiment that higher TLI resulted in higher DW. On D 31, shoot DW was higher under $\mathrm{T} 1$ and $\mathrm{T} 4$, compared to that under $\mathrm{T} 2$ and T3. However, at harvest (day 35), there were no significant differences in FW, DW, and marketable FW among all treatments (Figures 5 and 6A), whereas leaf area in T2 group was significantly higher than that in T4 group (Figure 6B).

In this experiment, tipburn was observed on day 27 after sowing. On D 27, tipburn occurrence were 33.3\%, 25\%, $33.3 \%$, and $41.7 \%$ in $\mathrm{T} 1, \mathrm{~T} 2, \mathrm{~T} 3$, and $\mathrm{T} 4$, respectively. Tipburn occurred $100 \%$ for all treatments at 31 days after sowing (Figure 7A). On D 27, RGRs under T4 were significantly higher than other treatments, and there was no significant difference between T1 and T3. RGR was lowest under T2. However, in the end of the experiment, there was no significant difference in RGR among all treatments (Figure 7B).

Through regression analysis, a linear relationship between RGR and tipburn occurrence was obtained on day 27 after sowing:

$$
\mathrm{Y}=0.2838 \mathrm{x}+0.1202\left(\mathrm{R}^{2}=0.99\right)
$$

It indicates similarly that tipburn would appear when RGR is higher than 0.1202 . RGR $<0.12$ seemed to be a key point to reduce tipburn occurrence (Figure 8).

\section{Discussion}

\section{Higher TLI results in greater plant growth and high RGR value}

High light intensity usually results in great plant growth and high RGR value in lettuce (Gaudreau et al., 1995; Shimizu et al., 2004; Kang et al., 2013; Shen et al., 2014; Kawasaki et al., 2015). A previous research in lettuce showed that the biomass of lettuce was highest under $600 \mu \mathrm{mol} \mathrm{m} \mathrm{m}^{-2} \mathrm{~s}^{-1}$ and was lowest under $100 \mu \mathrm{mol} \mathrm{m}^{-2} \mathrm{~s}^{-1}$ (Fu et al., 2012). In our study, the growth parameters of lettuce were promoted under high TLI values in both experiments. RGR value of lettuce were highest under $\mathrm{H}$ treatment and were lowest under $\mathrm{L}$ treatment in the first experiment (Figure 3B). He and Zhong (2000) demonstrated that RGR decreased with decrease in light intensity, which was in consistent with our results. Similar trend has been shown in different crops, such as cucumber, that RGR was significantly positively correlated with light intensity in three genotypes of cucumber seedlings (Ahn et al., 2014).

Although the shoot FW were significantly affected by light intensities, there was no significant difference in leaf area among different light intensity treatments (Figure 2A). Leaf area development determines light interception of a plant (Gifford et al., 1984; Maddonni and Otegui, 1996). Therefore, this result indicated that plants preferentially develop leaf area to increase capacity of light interception when light intensity is low. Consequently, the LMA increased with the increases of light intensity due to the difference in shoot dry weight (Figure 2B).

\section{Different lighting strategies in a short period did not affect final plant production when TLIs were equal}

In the Exp. 2, shoot and root DWs under T4 were higher than other treatments and significantly higher than T2 on D 27 , because of the TLI in T4 (46.1 $\left.\mathrm{mol} \mathrm{m}^{-2}\right)$ was the highest and in $\mathrm{T} 2\left(23.0 \mathrm{~mol} \mathrm{~m}^{-2} \mathrm{~d}^{-1}\right)$ was the lowest among all treat-

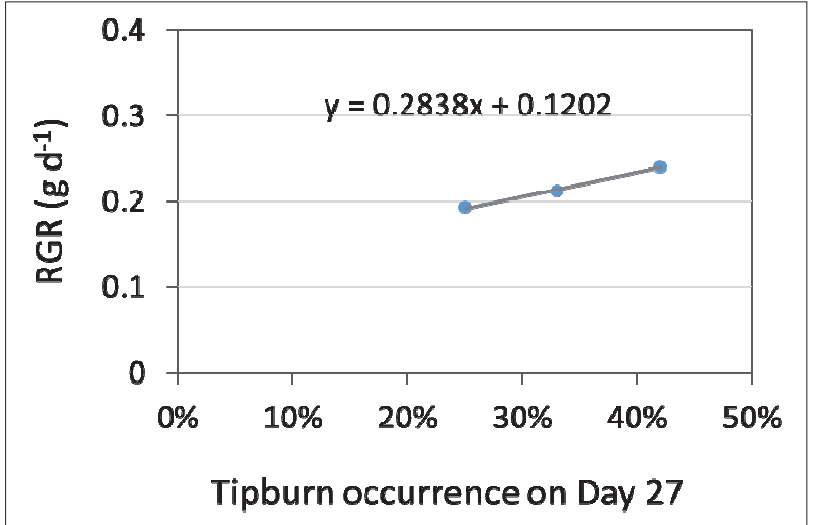

FIGURE 8. Relation between RGR and tipburn occurrence in Romaine lettuce plants under different light treatments at 27 days after sowing.

ments (Figure 5; Table 2). Similar trends were observed on D 31, that shoot and root DWs were higher under T1 and T4 than those under T2 and T3 (Figure 5C, D). However, the temporary promotion of plant growth was reversed by the last short period light treatment when controlling the TLI of the whole growth period to be the same. On day 35, the end of the experiment, the TLIs ( $\left.103.7 \mathrm{~mol} \mathrm{~m}^{-2}\right)$ were same in all treatments, and there was no significant difference in shoot and root FW and DW among all treatments (Figure 5) anymore. The result showed that applying different light intensities at different growth stages did not affect plant production when TLIs were equal. This is likely because dry mass accumulation is proportional to the light integral in lettuce plants (Albright et al., 2000).

\section{High RGR caused high tipburn occurrence and the key threshold in RGR to control tipburn occurrence}

In this study, tipburn occurrences were observed on D 26 and D 27 after sowing for the Exp. 1 and 2 respectively, indicating that tipburn occurred during 23 27 days after sowing. The tipburn became visible from D 26 and affected by different light intensity treatments under the conditions of the present study. Higher light intensity and higher TLI induced higher tipburn occurrence (Figures $3 \mathrm{~A}$ and $7 \mathrm{~A}$ ). This is positively related to the higher RGR. Collier and Tibbitts (1982) reported that higher RGR values associated with a high assimilatory activity in the leaves, lead to a lack of calcium in the young developing leaves, which finally results in tipburn development.

A linear relationship between RGR and tipburn occurrence was obtained. In the Exp. 1, the tipburn appeared on D 26, where a relationship of $Y=0.0028 x+0.1214$ was derived (Figure 4). And in the Exp. 2, the tipburn appeared on day 27 where a relationship of $Y=0.2838 x+0.1202$ was derived (Figure 8). These two formulas indicated that tipburn would appear when RGR is higher than a threshold value, about 0.12 . Therefore, to keep an RGR $<0.12$ could be a key point to reduce tipburn occurrence from 23 days after sowing. This is consistent with the result in the first experiment. On D 23, RGR value was 0.11 and tipburn occurrence was 0 under all treatments. On D 32, tipburn occurrence of lettuce under $\mathrm{L}$ treatment did not increase compared to that on D 29 (Figure 3), because the RGR was 0.11 after D 29. But the tipburn occurrence in $\mathrm{M}$ and $\mathrm{H}$ treatments kept increasing when RGR kept higher than 0.12 . Therefore, controlling the RGR value to be lower than 0.12 could prevent or inhibit the tipburn occurrence. 


\section{Conclusion}

This study investigated the effects of PPFD and lighting strategies on the growth and tipburn occurrence in lettuce plants grown in a plant factory. The results show that lettuce shoot and root FW and DW clearly increased with increases of light intensity (or TLI) and were not affected by different lighting strategies used in this study when TLIs were equal. Tipburn occurrence showed a positive relation with light intensity and RGR, and it occurred during $23 \sim 27$ days after sowing under the conditions in the present study. Regression analysis indicated that tipburn would appear when an RGR higher than a threshold value of $0.12 \mathrm{~g} \mathrm{~d}^{-1}$. To control an RGR lower than 0.12 during day $23 \sim 26$ is critical for limiting tipburn occurrence. The results obtained in this research are considered to be an important reference for producers who growing lettuce in plant factory condition for biomass production and inhibit tipburn occurrence by regulating PPFD (or TLI) and RGR.

\section{References}

Ahn, D., Higashide, T., Nakano, A., Kawasaki, Y., and Iwasaki, Y. (2014). Influence of light intensity on growth and $\mathrm{CO}_{2}$ assimilation rates of three genotypes of cucumber seedlings grown in chambers. Acta Hortic. 1037, 759-764. https://doi.org/10.17660/ ActaHortic.2014.1037.99.

Albright, L.D., Both, A.J., and Chiu, A.J. (2000). Controlling greenhouse light to a consistent daily integral. Trans. ASAE 43, 421-431. https:// doi.org/10.13031/2013.2721.

Barta, D.J., and Tibbitts, T.W. (1991). Calcium localization in lettuce leaves with and without tipburn: comparison of controlledenvironment and field-grown plants. J. Am. Soc. Hortic. Sci. 116, 870-875. https://doi.org/10.21273/JASHS.116.5.870.

Choi, K.Y., and Lee, Y.B. (2004). Effect of air temperature on tipburn incidence of Butterhead and Leaf lettuce in a Plant Factory. J. Am. Soc. Hortic. Sci. 44, 805-808.

Collier, G.F., and Tibbitts, T.W. (1982). Tipburn of lettuce. Hortic. Rev. 4, 49-65. https://doi.org/10.1007/978-1-349-06519-6_2.

Collier, G.F., and Tibbitts, T.W. (1984). Effects of relative humidity and root temperature on calcium concentration and tipburn development in lettuce. J. Am. Soc. Hortic. Sci. 109, 128.

Corriveau, J., Gaudreau, L., Caron, J., Jenni, S., and Gosselin, A. (2012). Testing irrigation, day/night foliar spraying, foliar calcium and growth inhibitor as possible cultural practices to reduce tipburn in lettuce. Can. J. Plant Sci. 92, 889-899. https://doi.org/10.4141/ cjps2011-242.

Cox, E.F., McKee, J.M.T., and Dearman, A.S. (1976). The effect of growth rate on tipburn occurrence in lettuce. J. Pomol. Hortic. Sci. 51, 297-309. https://doi.org/10.1080/00221589.1976.11514693.

Cresswell, G.C. (1991). Effect of lowering nutrient solution concentration at night on leaf calcium levels and the incidence of tipburn in lettuce (var. Gloria). J. Plant Nutr. 14, 913-924. https:// doi.org/10.1080/01904169109364252.

Fu, W., Li, P., Wu, Y., and Tang, J. (2012). Effects of different light intensities on anti-oxidative enzyme activity, quality and biomass in lettuce. Hort. Sci. (Prague) 39, 129-134. https://doi. org/10.17221/192/2011-HORTSCI.

Gaudreau, L., Charbonneau, J., Vezina, L.P., and Gosselin, A. (1995). Effects of photoperiod and photosynthetic photon flux on nitrate content and nitrate reductase activity in greenhousegrown lettuce. J. Plant Nutr. 18, 437-453. https://doi. org/10.1080/01904169509364914.
Gifford, R.M., Thorne, J.H., Hitz, W.D., and Giaquinta, R.T. (1984). Crop productivity and photoassimilate partitioning. Science 225, 801-808. https://doi.org/10.1126/science.225.4664.801.

Goto, E. (1992). Prevention of lettuce tipburn by supplying air to inner leaves. Trans. ASAE 35, 641-645. https://doi. org/10.13031/2013.28644.

Goto, E., and Takakura, T. (2003). Reduction of lettuce tipburn by shortening day/night cycle. J. Agric. Meteorol. 59, 219-225. https:// doi.org/10.2480/agrmet.59.219.

He, W., and Zhong, Z. (2000). Morphological and growth responses of the climbing plant, Gynostemma pentaphyllum seedlings to varying light intensity. Acta Phytoecol. Sin. 24, 375-378.

Huett, D.O. (1994). Growth, nutrient uptake and tipburn severity of hydroponic lettuce in response to electrical conductivity and K:Ca ratio in solution. Crop Pasture Sci. 45, 251-267. https://doi. org/10.1071/AR9940251.

Kang, J.H., Krishnakumar, S., Atulba, S.L.S., Jeong, B.R., and Hwang, S.J. (2013). Light intensity and photoperiod influence the growth and development of hydroponically grown leaf lettuce in a closed-type plant factory system. Hortic. Environm. Biotechnol. 54, 501-509. https://doi.org/10.1007/s13580-013-0109-8.

Kawasaki, S.I., Tominaga, J., Yabuta, S., Watanabe, K., Jaiphong, T., Ueno, M., and Kawamitsu, Y. (2015). Responses of growth, photosynthesis, and associated components to hypoxia at different light intensities in red leaf lettuce. Sci. Hortic. 193, 330-336. https:// doi.org/10.1016/j.scienta.2015.07.029.

Kozai, T., Niu, G., and Takagaki, M. (2015). Plant Factory: An Indoor Vertical Farming System for Efficient Quality Food Production (Amsterdam: Academic Press).

Maddonni, G.A., and Otegui, M.E. (1996). Leaf area, light interception, and crop development in maize. Field Crop. Res. 48, 81-87. https:// doi.org/10.1016/0378-4290(96)00035-4.

Misaghi, I.J., and Grogan, R.G. (1978). Effect of temperature on tipburn development in head lettuce. Phytopathology 68, 1738-1743. https://doi.org/10.1094/Phyto-68-1738.

Sago, Y. (2016). Effects of light intensity and growth rate on tipburn development and leaf calcium concentration in Butterhead lettuce. Hortscience 51, 1087-1091. https://doi.org/10.21273/ HORTSCI10668-16.

Shen, Y., Guo, S., Ai, W., and Tang, Y. (2014). Effects of the red and blue LED light intensity on lettuce growth and photosynthetic rate in a closed system. Manned Spaceflight 20, 273-278.

Shimizu, H., Kushida, M., Fujinuma, W., Sekine, M., Kaiho, K., Arai, H., and Shibusawa, S. (2004). Effect of solution temperature, light intensity and light in combination with sunlight using mirror duct on growth of Leaf lettuce (Lactuca sativa L. cv. Greenwave). Shokubutsu Kankyo Kogaku 16, 115-121. https://doi.org/10.2525/ jshita.16.115.

Son, J.E., and Takakura, T. (2010). Effect of EC of nutrient solution and light condition on transpiration and tipburn injury of lettuce in a plant factory. J. Agric. Meteorol. 44, 253-258. https://doi. org/10.2480/agrmet.44.253.

Tibbitts, T.W., and Rao, R.R. (1968). Light intensity and duration in the development of lettuce tipburn. Proc. Am. Soc. Hortic. Sci. 93, 454-461.

Tong, Y., Yang, Q., and Shimamura, S. (2014). Analysis of electricenergy utilization efficiency in a Plant Factory with artificial light for lettuce production. Acta Hortic. 1037, 277-284. https://doi. org/10.17660/ActaHortic.2014.1037.32. 
Zhang, X., He, D., Niu, G., Yan, Z., and Song, J. (2018). Effects of environment lighting on the growth, photosynthesis, and quality of hydroponic lettuce in a plant factory. Int. J. Agric. Biol. Eng. 11, 33-40. https://doi.org/10.25165/j.ijabe.20181102.3240.

Received: May 15, 2019

Accepted: Nov. 21, 2019

Addresses of authors:

Wenshuo $\mathrm{Xu}^{1}$, Duyen T.P. Nguyen ${ }^{1}$, Shunsuke Sakaguchi ${ }^{2}$, Takuji Akiyama ${ }^{2}$, Satoru Tsukagoshi ${ }^{3}$, Alexander Feldman ${ }^{3}$ and $\mathrm{Na} \mathrm{Lu}^{3, *}$

${ }^{1}$ Graduate School of Horticulture, Chiba University, 648 Matsudo, Chiba 271-8510, Japan

2 PlantX Corporation, Wakashiba, Kashiwa, Chiba 2770882, Japan

${ }^{3}$ Center for Environment, Health and Field Sciences, Chiba University, 6-2-1 Kashiwanoha, Kashiwa, Chiba 2770882, Japan

* Corresponding author; E-mail: na.lu@chiba-u.jp Tel./Fax: +81-047-137-8103 
International Workshop on Vertical Farming

13-15 October 2019

Wageningen, The Netherlands

Sponsored by
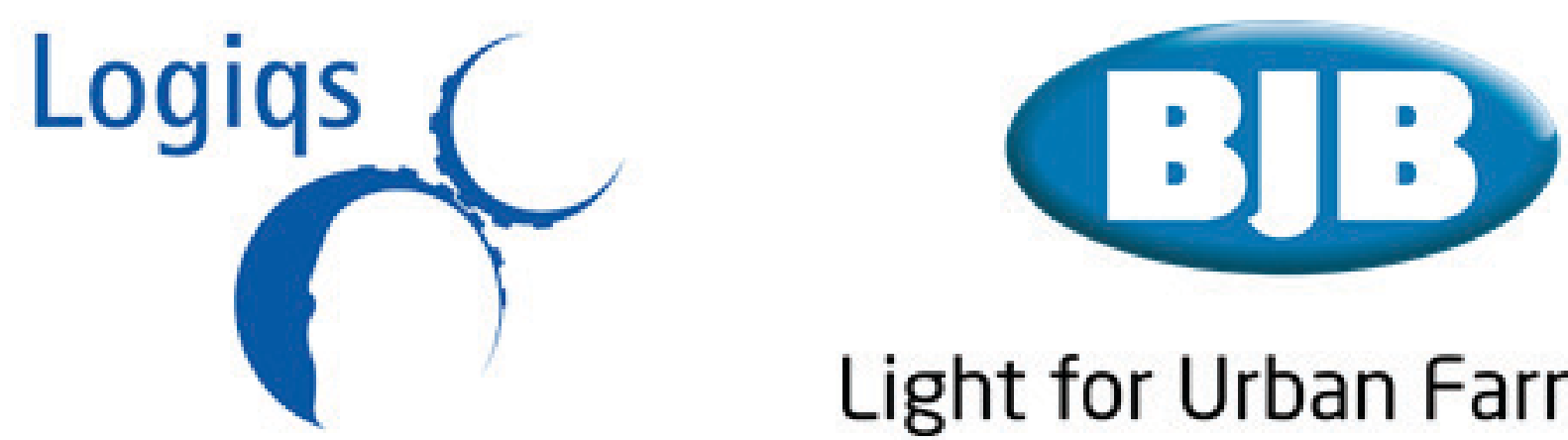

\section{Light for Urban Farming}

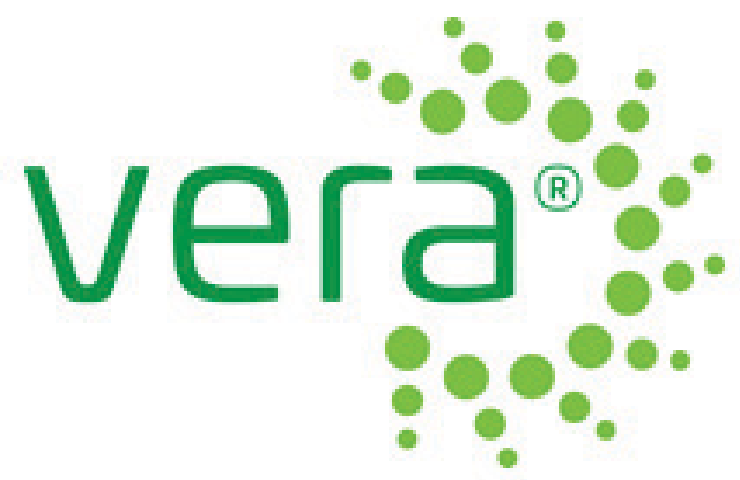

Nouryon

\section{Chelated} Micronutrients


Fடㅁㅁய

$$
\text { F L U E N C E }
$$

